\title{
Overwintering survival and regrowth of the invasive plant Eichhornia crassipes are enhanced by experimental warming in winter
}

\author{
Wenhua You, Dan Yu*, Dong Xie, Lingfei Yu
}

The National Field Station of Lake Ecosystem of Liangzi Lake, College of Life Science, Wuhan University, Wuhan, 430072, PR China

\begin{abstract}
The distribution of the invasive aquatic plant Eichhornia crassipes is considered to be limited by winter survival. Therefore, winter warming, as well as characteristics of overwintering organs, are expected to affect its distribution and survival. An experiment was conducted to analyze the effects of winter warming and stem base treatments (size or burial) on winter survival, regrowth and thus performance of floating or rooted plants of E. crassipes using a simulated warming system in a greenhouse. Winter warming significantly increased the percentage survival in both forms of the plant and facilitated its regrowth and clonal propagation. Stem base size played an important role in determining survival, regrowth and vegetative propagation. Moreover, water cover and sediment burial of stem bases facilitated overwintering. After winter survival, a larger fraction of the biomass of E. crassipes was allocated to shoots. These results suggest that, with climate warming, the invasive ability of E. crassipes will be enhanced, with distribution spreading to the north into central and north China, favouring plants with large stem bases.
\end{abstract}

KEY WORDS: Biomass allocation $\cdot$ Sediment burial $\cdot$ Stem base $\cdot$ Survival rate $\cdot$ Winter warming

Resale or republication not permitted without written consent of the publisher

\section{INTRODUCTION}

The distribution of the invasive aquatic plant Eichhornia crassipes (Mart) Solms is considered to be limited to tropical or subtropical regions (Aurand 1982, Tyndall 1982, Madsen et al. 1993). Based on recent climate change models, the distribution of E. crassipes will expand into higher latitudes under climate warming (Hellmann et al. 2008, Rahel \& Olden 2008). Indeed, climate warming in winter is more significant than that in summer (Karl et al. 1993). For example, over the past $40 \mathrm{yr}$, the mean summer temperature in China did not change significantly but the mean winter temperature increased up to $0.42^{\circ} \mathrm{C}$ every $10 \mathrm{yr}$ (Ding 1997). In the context of future climate warming, few studies have addressed the effects of winter warming on winter survival and the distribution range of this invasive plant (Owens \& Madsen 1995).

Winter survival is a complex process that does not solely depend on a plant's ability to endure the direct effects of extreme low temperature. During long overwintering periods, plants are exposed to multiple environmental stresses, such as drought, flooding and ice cover (Bertrand \& Castonguay 2003). In aquatic ecosystems associated with flooding, sedimentation can cause burial of aquatic plants by sand (Lowe et al. 2010, Pan et al. 2012). Previous studies have demonstrated that burial may change abiotic and biotic conditions such as light radiation (Brown 1997), temperature (Baldwin \& Maun 1983, Zhang \& Maun 1990) and activity of pathogens (van der Putten et al. 1993, D'Hertefeldt \& van der Putten 1998), thus modifying plant morphology and physiology, and affecting survival and growth (Little \& Maun 1996, Maun 1998, Yu et al. 2002). Moreover, organic reserves in plant tissue are critical for winter stress tolerance and rapid regrowth (Volenec et al. 1996). Storage organs, such as stolons and stem bases, can store soluble carbohydrates and proteins that can be retranslocated among interconnected ramets to 
improve the survival and growth of clonal plants under natural disturbances and environmental stresses (Madsen et al. 1993, Stuefer \& Huber 1999, Dong et al. 2010). Therefore, greater stored resources contained in larger storage organs can be retranslocated to attached ramets and may facilitate the biomass accumulation and production of new ramets (Danckwerts \& Gordon 1989, Baur-Höch et al. 1990, Stuefer \& Huber 1999). Although sediment burial and storage organ size may contribute to winter survival and regrowth of plants during the overwintering period, their effects on overwintering of plants are still largely unknown, especially for invasive aquatic plants.

Biomass allocation is a fundamental aspect of the competive ability of invasive aquatic plants, which often allocate a large fraction of their biomass to form canopy and to support the rapid spring growth that allows them to suppress other species (Madsen 1991, Sytsma \& Anderson 1993). For instance, 2 invasive aquatic plants, water hyacinth Eichhornia crassipes and alligator weed Alternanthera philoxeroides, can form dense stands above the water surface that exclude almost all other species (Aston 1977, Julien \& Bourne 1988). Villamagna \& Murphy (2010) stated that greater allocation to shoots may enhance water hyacinth's ability to shade out other aquatic plants and algae in the water column. However, to our knowledge, little information exists on the effects of winter warming on the biomass allocation pattern of regrowth after winter survival for invasive aquatic plants.

Eichhornia crassipes, originating from tropical South America, is a mat-forming aquatic plant with floating and rooted forms, and is one of the world's most prevalent invasive aquatic plants, causing severe ecological and socio-economic changes in invaded habitats (Center 1994, Villamagna \& Murphy 2010). It is thermophilous and is regarded as one of the fastest-growing plants in the world when conditions are favorable (Abbasi \& Nipaney 1986, Abbasi 1998). Water hyacinth was introduced into China as an ornamental plant in the early 1900s and is now widely distributed in 17 provinces or cities and causes severe damage in more than 10 provinces. In several other provinces, E. crassipes is still being planted but it cannot overwinter (Ding et al. 1995). Previous studies have demonstrated that low winter temperature is a major limiting factor in its overwintering survival and thus determines the northern boundary of its distribution (Aurand 1982, Luu \& Getsinger 1990). Mature plants consist of shoots (leaves and petioles), stem bases (short stems) and roots, producing new plants apically by stolons (Abbasi 1998). The stem base is the overwintering organ of the water hyacinth, in which carbohydrates can be stored as energy reserves to withstand low temperature stress (Madsen et al. 1993). Owens \& Madsen (1995) found that exposure to low-temperature (below $5^{\circ} \mathrm{C}$ ) conditions for long periods could markedly increase the mortality rate of the plants, thereby affecting the overwintering capacity of E. crassipes in cold winters.

We conducted a greenhouse experiment to investigate the effects of simulated winter warming and stem base treatments (size or burial) on winter survival, regrowth and thus performance of floating or rooted forms of Eichhornia crassipes. Specifically, we tested the following hypotheses: (1) the percentage survival of E. crassipes will be improved by winter warming; (2) a larger stem base (more storage material), water cover and sediment burial of the stem base (temperature protection) can facilitate winter survival and regrowth of E. crassipes; and (3) after winter survival, biomass allocation to shoots of $E$. crassipes will increase to support its rapid propagation and spread under winter warming conditions.

\section{MATERIALS AND METHODS}

\section{Study site}

The experiments were conducted in glasshouses at Liangzi Lake in the Hubei province of south-central China $\left(30^{\circ} 05^{\prime}-30^{\circ} 18^{\prime} \mathrm{N}, 114^{\circ} 21^{\prime}-114^{\circ} 39^{\prime} \mathrm{E}\right)$. Liangzi Lake is a shallow, mesotrophic lake of intermediate area located on the central reaches of the Yangtze River. Average winter temperatures range from 3.0 to $7.0^{\circ} \mathrm{C}$ in this region (Liu \& Yu 2009).

\section{Plant material}

In early December 2008, a large number of healthy Eichhornia crassipes were collected from Liangzi Lake and cultivated in a greenhouse. One week later, 480 ramets were divided into 2 subsets according to the size of the stem base (small: $\mathrm{n}=360$ ramets, diameter $=0.65 \pm 0.09 \mathrm{~cm}$, length $=2.0 \pm 0.38 \mathrm{~cm}$; large: $\mathrm{n}=120$ ramets, diameter $=1.0 \pm 0.15 \mathrm{~cm}$, length $=3.5 \pm 0.30 \mathrm{~cm}$ ) and used for further experiments.

\section{Experimental design}

Simulated warming system in the greenhouse

A simulated warming system was set up in a greenhouse with the south door open to produce a southnorth temperature gradient (Fig. 1A) at The National 

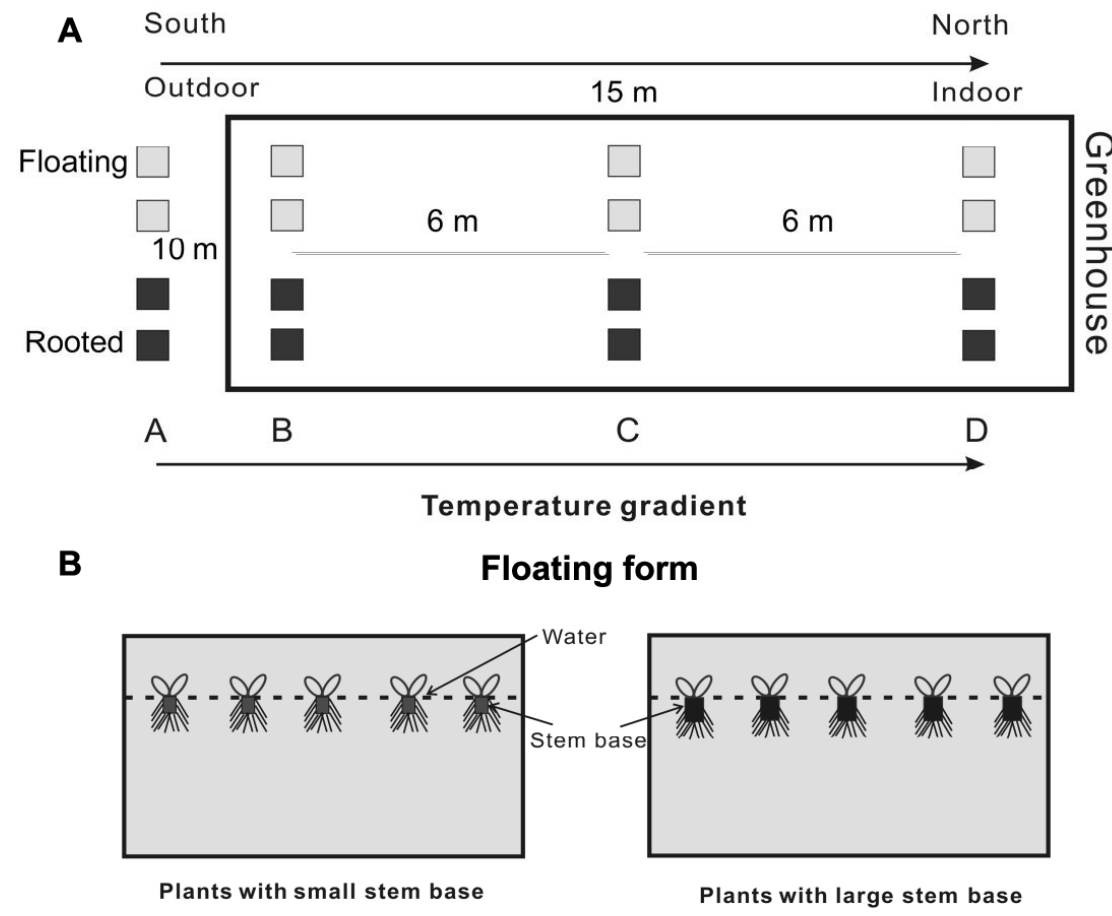

Rooted form

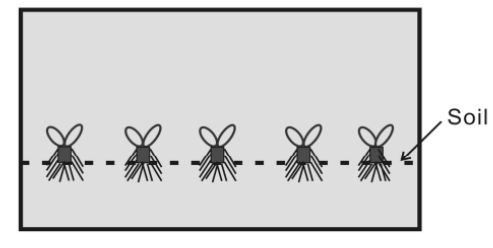

Plants without stem base buried

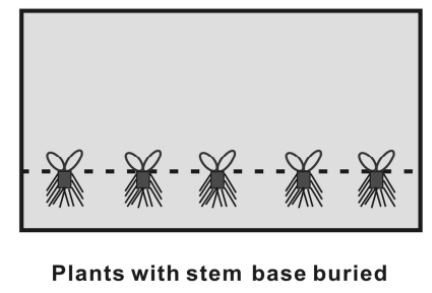

Plants with stem base buried
Fig. 1. Schematic representation of the experimental design. (A) Simulated warming system in the greenhouse; (B) stem base treatments of Eichhornia crassipes (stem base size for the floating form; sediment burial for the rooted form)

Field Station of Lake Ecosystem of Liangzi Lake, Wuhan University. This system was passively warmed by solar radiation, and a thermal current flowed from the north of the greenhouse to the south through the exchange of indoor warm air and outdoor cool air via the opened south door. A temperature gradient of approximately $4^{\circ} \mathrm{C}$ from south to north (marked as A, B, C, D, from outside to inside, in Fig. 1A) was simulated in winter rising about $1^{\circ} \mathrm{C}$ at $6 \mathrm{~m}$ intervals (Table 1). The elevated temperature was within the average temperature increase am-
Table 1. Microclimate parameters (mean $\pm \mathrm{SE}$ ) of the simulated warming system during the experimental period and ANOVA results for each parameter along the temperature gradient. Values with different superscripted letters are significantly different from each other within a column $\left({ }^{*} \mathrm{p}<0.05{ }^{* *} \mathrm{p}<0.01{ }^{* * *} \mathrm{p}<0.001\right.$; ns: not significant)

\begin{tabular}{|c|c|c|c|c|c|}
\hline \multirow{2}{*}{$\begin{array}{l}\text { Temperature } \\
\text { gradient }\end{array}$} & \multirow{2}{*}{$\begin{array}{l}\mathrm{CO}_{2} \text { concen- } \\
\text { tration (ppm) }\end{array}$} & \multirow{2}{*}{$\begin{array}{l}\text { Light intensity } \\
\left(\mu \mathrm{mol} \mathrm{m}{ }^{-2} \mathrm{~s}^{-1}\right)\end{array}$} & \multicolumn{3}{|c|}{ - Temperature } \\
\hline & & & Air $\left({ }^{\circ} \mathrm{C}\right)$ & Water $\left({ }^{\circ} \mathrm{C}\right)$ & Soil $\left({ }^{\circ} \mathrm{C}\right)$ \\
\hline A & $378.6 \pm 1.2$ & $900 \pm 13$ & $4.8 \pm 0.2^{\mathrm{a}}$ & $6.1 \pm 0.2^{\mathrm{a}}$ & $5.9 \pm 0.1^{\mathrm{a}}$ \\
\hline B & $378.4 \pm 1.1$ & $904 \pm 10$ & $6.2 \pm 0.1^{b}$ & $7.2 \pm 0.2^{\mathrm{b}}$ & $7.0 \pm 0.1^{b}$ \\
\hline $\mathrm{C}$ & $379.1 \pm 1.4$ & $901 \pm 12$ & $7.3 \pm 0.2^{\mathrm{c}}$ & $8.1 \pm 0.1^{\mathrm{c}}$ & $8.0 \pm 0.1^{\mathrm{c}}$ \\
\hline $\mathrm{D}$ & $378.9 \pm 0.9$ & $898 \pm 12$ & $8.2 \pm 0.1^{\mathrm{d}}$ & $8.9 \pm 0.2^{\mathrm{d}}$ & $8.8 \pm 0.2^{\mathrm{d}}$ \\
\hline$F_{3,63}$ & $0.49^{\text {ns }}$ & $1.30^{\mathrm{ns}}$ & $65.72^{* * *}$ & $49.66^{* * *}$ & $163.24^{* * *}$ \\
\hline
\end{tabular}

plitude in $2100\left(1.4-5.8^{\circ} \mathrm{C}\right)$ predicted by the IPCC (IPCC 2007). Microclimate parameters including temperature (air, water and soil), light intensity and air $\mathrm{CO}_{2}$ concentration were monitored using a weather station (PC-3, Jinzhou Sunshine Technology), and none of these parameters exhibited any significant differences along the temperature gradient (except for temperature) during the 3-mo experimental period (Table 1). Based on our hypotheses, we set up 2 experiments using a 2-way factorial design. Both experiments started on 20 December 2008, and ended in late March 2009.

Expt 1: Floating formsimulated warming and variation in stem base size

For each temperature 'position' in the glasshouse (A, B, C and D, Fig. 1A), 8 aquaria $(50 \times 50 \times 45 \mathrm{~cm})$ were filled with lake water $\left(54.69 \mathrm{mmol} \mathrm{m}^{-3}\right.$ total nitrogen $[\mathrm{TN}], 1.41 \mathrm{mmol} \mathrm{m} \mathrm{m}^{-3}$ total phosphorus [TP]) at each temperature. Four aquaria were randomly selected and planted with 10 plants with small stem bases per aquarium, and the other 4 aquaria were planted with 10 plants with large stem bases per aquarium (Fig. 1B). Each aquarium was treated as a treatment unit, so each treatment was replicated 4 times. To mimic the natural environment in the lake, lake clay ( $3.55 \mathrm{mg} \mathrm{g}^{-1} \mathrm{TN}, 0.15 \mathrm{mg} \mathrm{g}^{-1} \mathrm{TP}$ ) was added to the bottom of each aquarium to a depth of $10 \mathrm{~cm}$. 
Expt 2: Rooted form—simulated warming and stem base burial

The warming system was the same as in Expt 1. At each temperature, 8 aquaria were filled with finetextured, homogeneous lake soil to a depth of $20 \mathrm{~cm}$. Forty plants with small stem bases were randomly transplanted to 4 aquaria with stem bases buried in $10 \mathrm{~cm}$ sediment. Additionally, 40 plants with small stem bases were planted in the other 4 aquaria with the stem bases exposed to air (Fig. 1B). Each treatment was replicated 4 times. Aquaria were kept welldrained and watered every other day.

\section{Data collection}

During the experimental period, diurnal variations of temperature (air, water and soil) were recorded by temperature loggers every half hour and the mean daily temperature was calculated (Table 1). Before harvest, the number of plants that survived was counted to calculate the winter percentage survival in each aquarium. The experiment was ended in late March 2009, and all the plants were harvested; the number of new ramets per plant in each aquarium was then counted. Each plant (including the initial plant and new ramets) was separated into shoot, stem and root, and their biomass was determined after drying to a constant weight at $70^{\circ} \mathrm{C}$ for $72 \mathrm{~h}$.

\section{Data analysis}

Before analysis, data were log-transformed if necessary, and percentage survival and biomass allocations were arcsine-transformed to meet assumptions of normality and homoscedasticity. One-way ANOVA was performed to examine the differences in microclimate parameters along the temperature gradient. Two-way ANOVA was used to test the effects of simulated warming and stem base treatments (size or burial) on percentage survival, mean biomass per plant, mean number of new ramets and percentage biomass allocation of Eichhornia crassipes. If a significant treatment effect was detected, post hoc pair-wise comparisons of means were carried out to examine differences between treatments using a studentized Tukey's HSD for multiple comparisons at the 0.05 significance level. All data analyses were performed using SPSS 17.0.

\section{RESULTS}

\section{Winter survival}

Warming, stem base size and their interaction had significant effects on the percentage survival of Eichhornia crassipes. The percentage survival of the large stem base plants was $100 \%$ at all temperature treatments, while that of the small stem base plants increased with increasing temperature, up to $100 \%$ in the maximum temperature treatment (Table 2, Fig. 2A). In Expt 2, warming, stem burial and their interaction significantly affected the percentage survival of E. crassipes. The percentage survival of the plants with stem bases buried in the sediment was markedly higher than that of plants with stem bases exposed to air. The percentage survival in both stem base treatments increased with temperature. All of the unburied plants died at the control temperature, while at the maximum temperature, plants in all treatments survived (Table 2, Fig. 2B).

\section{Regrowth after winter survival}

The number of new ramets per plant after winter survival was significantly affected by warming and stem base size, but not by their interaction (Table 2). The number of new ramets per plant was significantly greater in plants with large stem bases than in plants with small stem bases, and both increased with temperature (Table 2, Fig. 3A). Biomass per plant was much higher in plants with large stem bases than in plants with small stem bases, and both were significantly improved by warming (Table 2, Fig. 3B). In Expt 2, warming and stem base burial significantly affected the number of new ramets

Table 2. Effects of simulated winter warming and stem base treatments (size or burial) on percentage survival and growth measures of Eichhornia crassipes. ${ }^{*} \mathrm{p}<0.05{ }^{* *} \mathrm{p}<0.01 ;{ }^{* * *} \mathrm{p}<0.001$ (2-way ANOVA)

\begin{tabular}{|lccc|}
\hline & $\begin{array}{c}\text { Warming } \\
(\mathrm{W})\end{array}$ & $\begin{array}{c}\text { Stem base } \\
\text { treatment }(\mathrm{S})\end{array}$ & $\mathrm{W} \times \mathrm{S}$ \\
\hline Trait & $F_{3,24}$ & $F_{1,24}$ & $F_{3,24}$ \\
Floating form & & & \\
Percentage survival & $28.812^{* * *}$ & $15.950^{* * *}$ & $7.098^{* *}$ \\
Mean biomass of plant & $67.326^{* * *}$ & $29.597^{* * *}$ & $8.263^{* *}$ \\
Mean no. of new ramets & $4.985^{*}$ & $8.609^{*}$ & 1.885 \\
Rooted form & & & \\
Percentage Survival & $31.154^{* * *}$ & $22.984^{* * *}$ & $8.369^{* *}$ \\
Mean biomass of plant & $105.090^{* * *}$ & $18.650^{* *}$ & $8.819^{* *}$ \\
Mean no. of new ramets & $149.454^{* * *}$ & $6.472^{*}$ & 1.509 \\
\hline
\end{tabular}




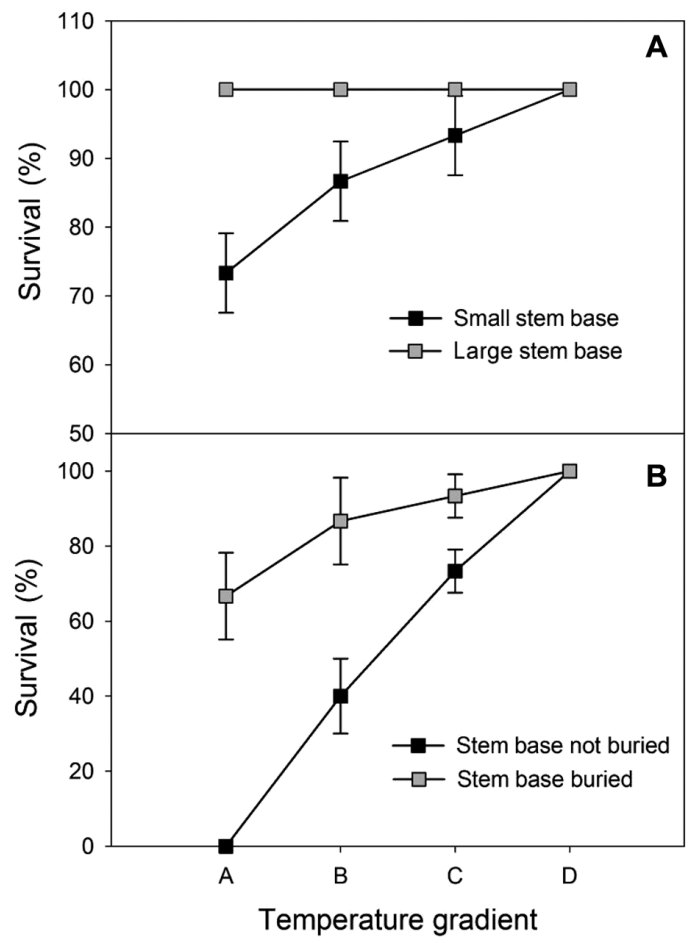

Fig. 2. Eichhornia crassipes. Percentage survival of E. crassipes along a temperature gradient: (A) with different sizes of stem base and (B) with and without stem bases buried by sediment. Data are means $\pm \mathrm{SE}$
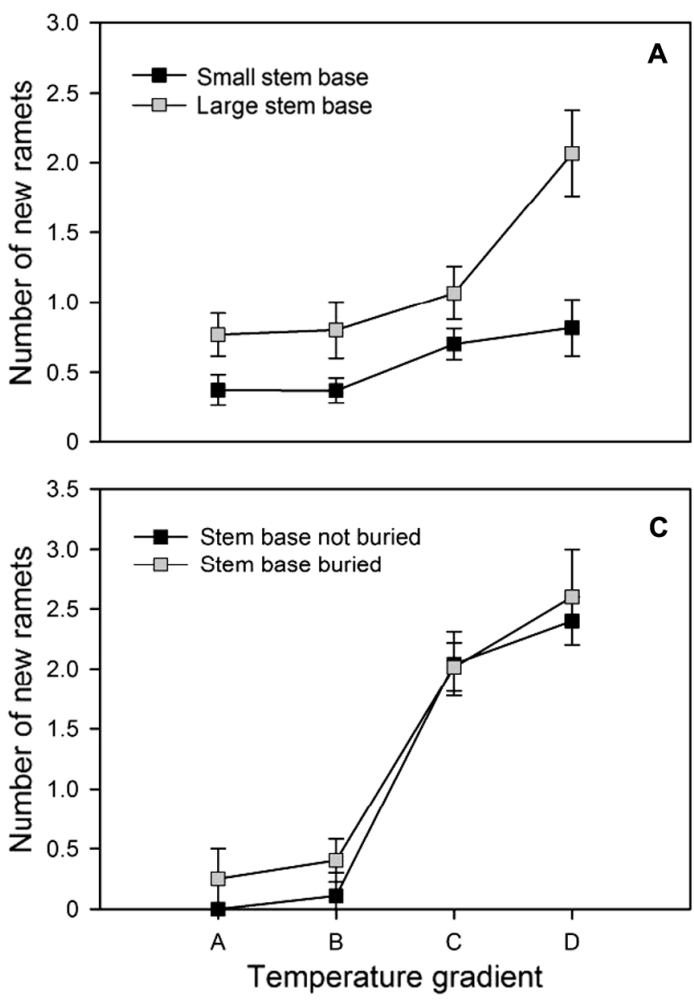

per plant, but their interaction was not significant (Table 2). The number of new ramets per plant was greater in plants with the stem base buried than in plants plants with the stem base unburied, and both increased with temperature (Table 2, Fig. 3C). Biomass per plant was significantly affected by the 2 factors (warming, stem base burial) and their interaction, and the responses in terms of biomass to the 2 factors were similar to that of number of new ramets per plant (Table 2, Fig. 3D).

\section{Biomass allocation after winter survival}

In summary, warming and stem base size both had significant effects on biomass allocation in Eichhornia crassipes, but their interaction was not significant in Expt 1 (Table 3). Warming increased biomass allocation to the shoots and decreased that to the stems, and this effect was more notable in the plants with large stem bases. Biomass allocation to stems in plants with large stem bases was much higher than that in plants with small stem bases. Biomass allocation to roots was not affected by warming, but was significantly larger in plants with small stem bases than plants with large stem bases (Table 3, Fig. 4A-C). In
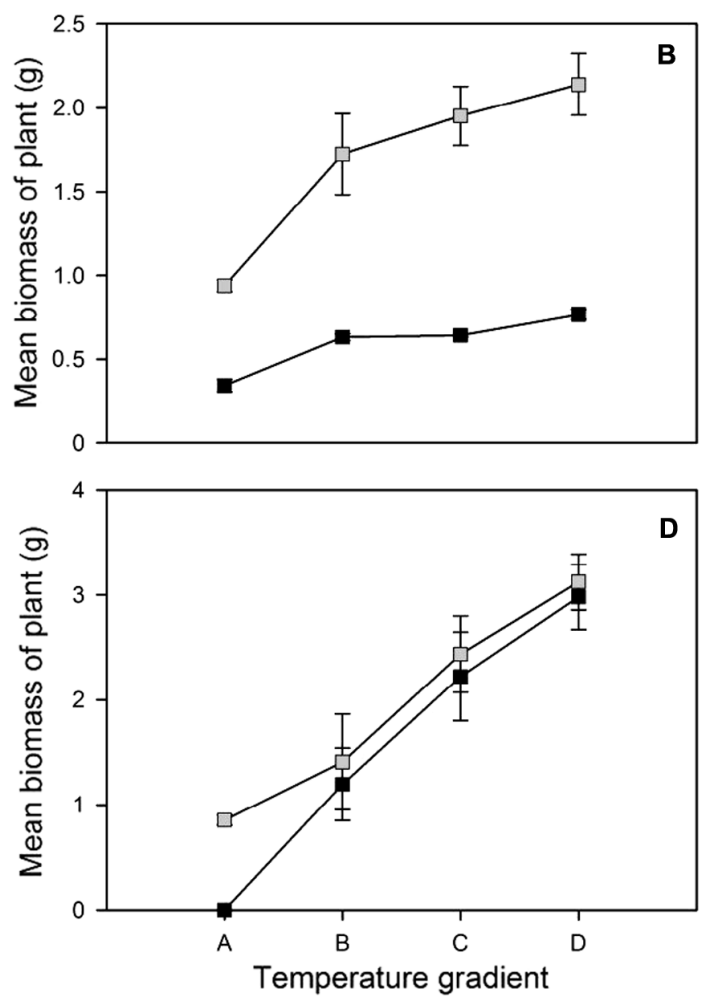

Fig. 3. Eichhornia crassipes. Number of new ramets per plant and mean biomass of E. crassipes with $(\mathrm{A}, \mathrm{B})$ different sizes of stem base for the floating form and $(C, D)$ with and without the stem base buried by sediment for the rooted form along a temperature gradient (see Table 1). Data are mean $\pm \mathrm{SE}$ 
Table 3. Effects of simulated winter warming and stem base treatments on percentage biomass allocation to the shoots, stems and roots of Eichhornia crassipes. ${ }^{*} \mathrm{p}<0.05{ }_{i}{ }^{* *} \mathrm{p}<$ $0.01 i^{* * *} \mathrm{p}<0.001$ (2-way ANOVA)

\begin{tabular}{|lccc|}
\hline & $\begin{array}{c}\text { Warming } \\
(\mathrm{W})\end{array}$ & $\begin{array}{c}\text { Stem base } \\
\text { treatment }(\mathrm{S})\end{array}$ & $\mathrm{W} \times \mathrm{S}$ \\
\hline Trait & $F_{3,24}$ & $F_{1,24}$ & $F_{3,24}$ \\
Floating form & & & \\
Shoot (\%) & $29.388^{* * *}$ & 0.747 & 1.429 \\
Stem (\%) & $35.826^{* * *}$ & $55.321^{* * *}$ & 4.695 \\
Root (\%) & 0.643 & $26.138^{* * *}$ & 0.795 \\
Rooted form & & & \\
Shoot (\%) & $72.482^{* * *}$ & 3.314 & 1.018 \\
Stem (\%) & 1.164 & 0.520 & 0.247 \\
Root (\%) & $36.328^{* * *}$ & 0.001 & 1.868 \\
\hline
\end{tabular}

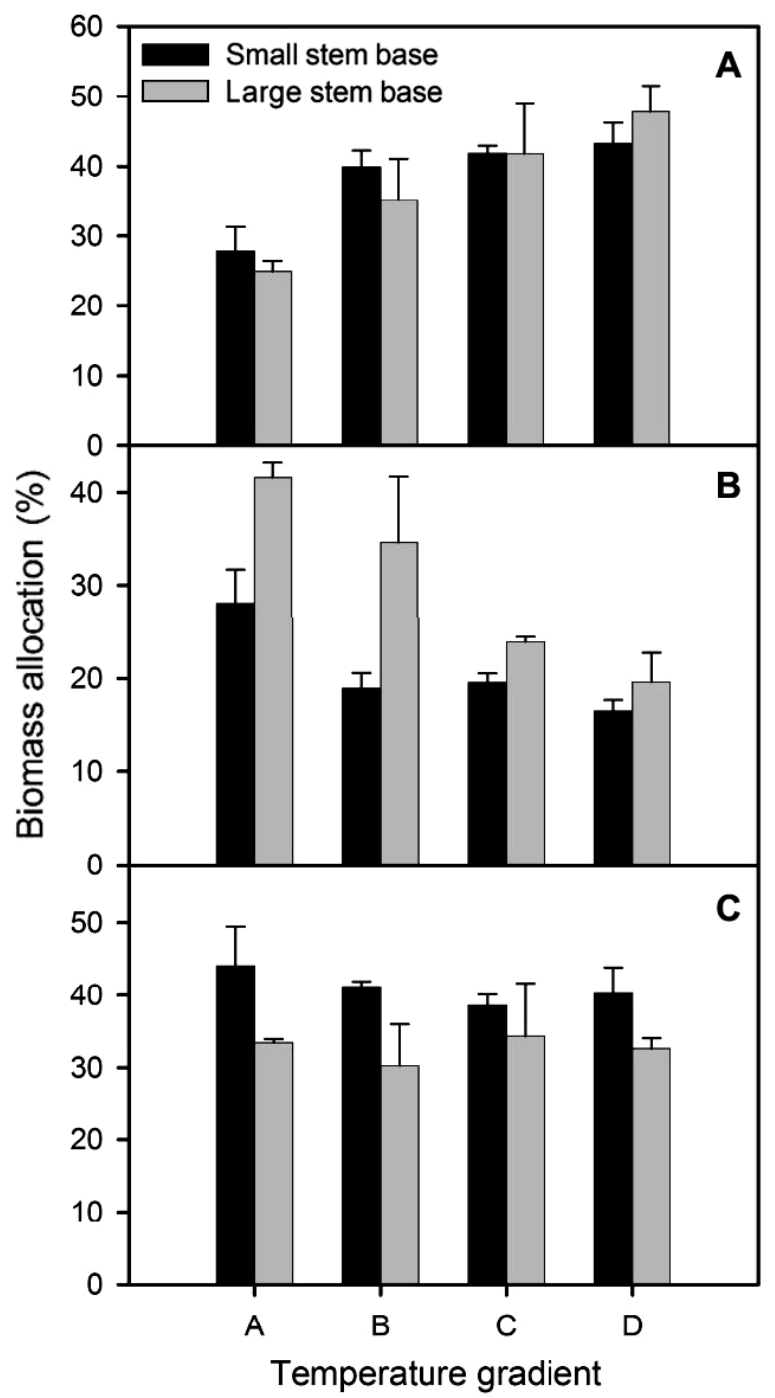

Expt 2, biomass allocation of E. crassipes was only significantly affected by winter warming (Table 3 ). Biomass allocation to shoots increased with increasing temperature at the expense of that to roots (Table 3, Fig. 4D-F).

\section{DISCUSSION}

In both experiments, winter survival rate of Eichhornia crassipes significantly increased with increasing temperature, up to $100 \%$ at the highest temperature. This was most likely due to winter warming buffering the damage caused by low temperatures. Previous studies (Li et al. 1995, Wilson et al. 2005) showed that survival, growth and clonal integration

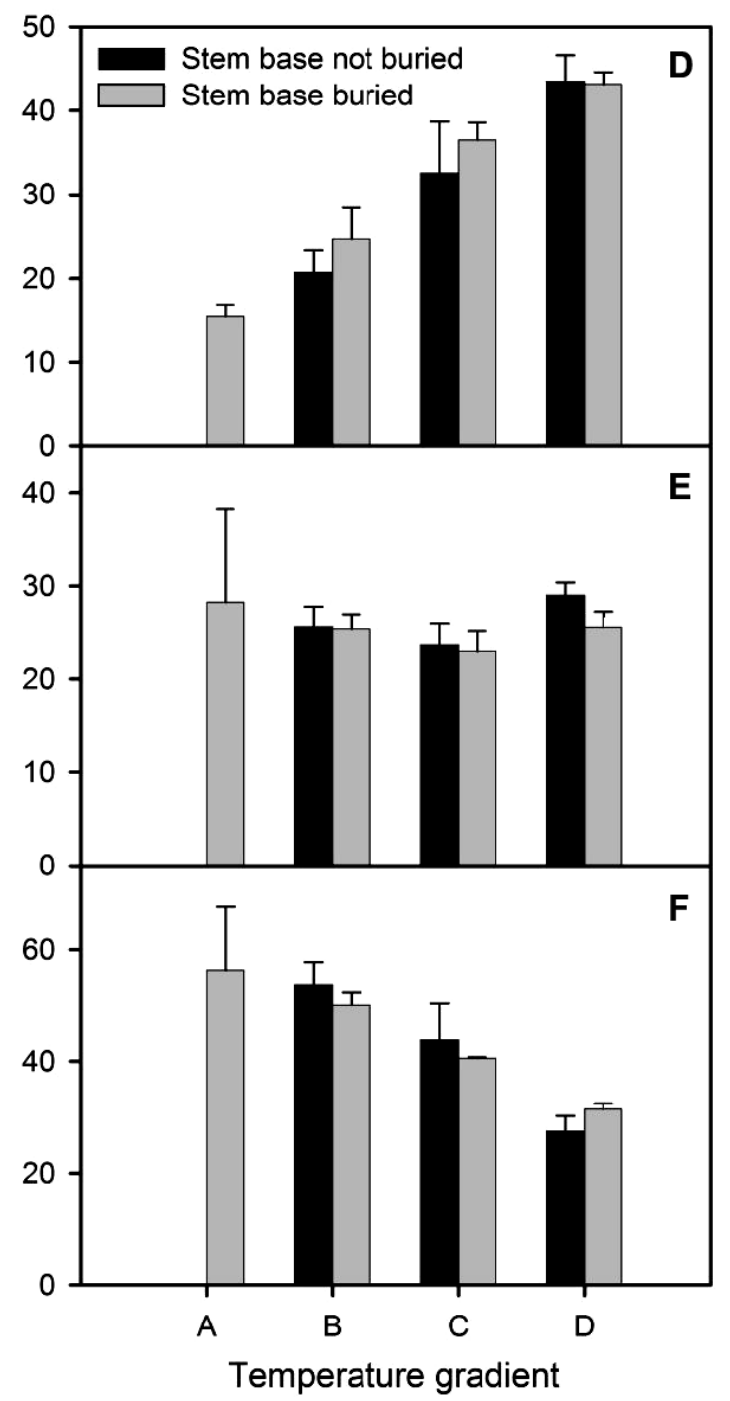

Fig. 4. Eichhornia crassipes. Biomass allocation to the $(A, D)$ shoot, $(B, E)$ stem and $(C, F)$ root along a temperature gradient (see Table 1) with (A-C) different sizes of stem base and with and (D-F) without stem bases buried by sediment. Data are mean \pm SE 
in E. crassipes were limited by low temperature (air temperature and water temperature). In our study, the percentage survival of this invasive plant was significantly improved by elevated temperature in winter, which supported our first hypothesis, suggesting that winter warming facilitates overwinter survival of E. crassipes and may influence its potential invasiveness into central and north China.

The survival rate of floating plants with small stem bases was much higher than that of rooted plants with unburied stem bases (87.2 versus $52.5 \%$ ). This is probably because water cover of stem bases can prevent direct damage from freezing. This result is in accordance with a previous study (Owens \& Madsen 1995), which also showed that the percentage survival of floating stem bases in Eichhornia crassipes populations decreased with the reduction of water levels due to the absence of temperature protection through water during winter. Moreover, stem bases buried in sediment are subject to temperatures differing from air temperature (Baldwin \& Maun 1983, Zhang \& Maun 1990), which may play a similar role in temperature buffering as does water cover. Thus, the percentage survival of rooted E. crassipes with stem bases buried deep in the sediment was higher than that of plants with stem bases exposed to the air. This is probably because the mean soil temperature was 0.6 to $1.1^{\circ} \mathrm{C}$ higher than the air temperature, and buried stem bases were protected from cold air temperatures by a thick layer of sediment and pieces of dead plants (Owens \& Madsen 1995). Therefore, lake bends may be perfect refuges for overwintering of $E$. crassipes and for its growth (and perhaps outcompetition of other species) in the following growing season, because the aquatic plants, plant detritus and the water itself can provide temperature protection for E. crassipes.

The survival rate of plants with large stem bases was much higher than that of plants with small stem bases. This is most likely because Eichhornia crassipes can store carbohydrates in the stem base during the fall as energy reserves to withstand environmental stresses such as low temperatures in winter (Madsen et al. 1993). More resources stored by large stem bases could result in more protective substances such as soluble carbohydrates and proteins (Morgan 1984). E. crassipes has no other mechanisms to survive low temperature except for seed dormancy (Larcher 1980). Thus, temperature buffering by the water body and more protective substances stored in the stem base may explain why the percentage survival of floating plants with large stem bases was greater than that of floating or rooted plants with small stem bases and was still $100 \%$ at the lowest temperature. Similarly, Fry (1993) found that survival rate of the stoloniferous terrestrial plant Eremochloa ophiruoides was positively correlated with carbohydrate content in the stolon internodes at low temperatures.

The number of new ramets and the mean biomass per plant after winter survival increased with temperature in all treatments. This is most likely because Eichhornia crassipes is a thermophilous aquatic plant (Abbasi \& Nipaney 1986, Abbasi 1998), thus moderate winter warming in our study promoted its growth and clonal propagation. The growth (in terms of number of new ramets and mean biomass per plant) of floating plants with large stem bases was greater than of plants with small stem bases. Dong et al. (2010) also found that the survival and growth of ramets of the invasive plant Alternanthera philoxeroides increased with the length of connected stolons after fragmentation. Although we did not measure the mobilization of carbohydrates and nitrogen in E. crassipes, we found that the stem bases were dramatically depleted, especially large stem bases. Thus, it is very likely that carbohydrates and nitrogen were mobilized and used by new ramets. These results suggest that the resources stored in the organs of clonal plants are very important for their survival and regrowth in stressful environments. The number of new ramets and the mean biomass per plant of rooted plants with stem bases buried were slightly higher than plants with unburied stem bases, but this trend was not significant, indicating that burial of the stem base mainly affected the percentage survival of the plants because of the limited stored resources in the small stem bases. These observations supported our second hypothesis, suggesting that stem base size is critical in overwintering, growth, clonal propagation and thus distribution of E. crassipes.

Biomass allocation in both plant forms was significantly modified by winter warming, suggesting that changes in resource allocation of Eichhornia crassipes may be an important mechanism for its adaption to changed environments (Xie et al. 2004). Biomass allocation to shoots (leaves and petioles) of floating plants increased with temperature at the expense of that to stems, in agreement with previous studies (Madsen 1991, Sytsma \& Anderson 1993), which showed that invasive aquatic plants often allocate a large fraction of their biomass to form canopy and support the rapid spring growth that allows them to suppress other species. In addition, this pattern of biomass allocation was more pronounced in plants with large stem bases (20.4 versus $10.5 \%$ decrease in biomass allocation to stems along the temperature 
gradient). This is probably because more resources stored in the large stem bases were used to support the rapid regrowth of E. crassipes, and the percentage of stem biomass decreased because of the resource depletion of the stem bases of the initial plant. In rooted plants, biomass allocation to shoots increased with temperature at the expense of that to roots. This result most likely occurred because rooted plants had limited resources in their stem bases, and nutrients in the sediment were much higher than that in the water, so plants could allocate a small fraction of their biomass to the roots to acquire sufficient nutrients to support their rapid regrowth and proliferation. The obtained results confirmed our third hypothesis, suggesting that greater allocation to shoots may enhance the water hyacinth's ability to shade out other aquatic plants and algae in the water column, thus increasing its competitive advantage after winter survival (Villamagna \& Murphy 2010).

In conclusion, winter warming and stem base characteristics (larger, covered by the water and buried in sediment) can facilitate winter survival of Eichhornia crassipes, and subsequently promote its regrowth and clonal propagation after winter survival. Moreover, allocating more biomass to shoots may allow the plants to form a canopy and result in suppression of other species in the following growth season. These results suggest that the invasion potential of E. crassipes populations to central and northern China may be enhanced and its normal distribution may extend northwards under climate warming (Hellmann et al. 2008, Rahel \& Olden 2008). Furthermore, lake bends may be suitable refuges for E. crassipes to survive winter and in turn become likely areas for its invasion. However, to allow generalization and robust extrapolation, more field studies are needed.

Acknowledgements. We gratefully thank the National Natural Science Foundation of China (30930011) for funding support.

\section{LITERATURE CITED}

Abbasi SA (1998) Weeds of despair and hope. In: Abbasi SA (ed) Wetlands of India, Vol 3. Discovery Publishing House, New Delhi, p 12-21

Abbasi SA, Nipaney PC (1986) Infestation by aquatic weeds of fern genus Salvinia: its status and control. Environ Conserv 13:235-241

Aston HI (1977) Appendix 1: the water hyacinth (Eichhornia crassipes). Aquatic plants of Australia. Melbourne University Press, Melbourne, p 333-339

Aurand D (1982) Nuisance aquatic plants and aquatic plant management programs in the United States, Vol 2, Southeastern Region. The Mitre Corporation, McLean, VA
Baldwin KA, Maun MA (1983) Microenvironment of Lake Huron sand dunes. Can J Bot 61:241-255

Baur-Höch B, Machler F, Nösberger J (1990) Effect of carbohydpercentage demand on the remobilization of starch in stolons and roots of white clover (Trifolium repens L.) after defoliation. J Exp Bot 41:573-578

> Bertrand A, Castonguay Y (2003) Plant adaptations to overwintering stresses and implications of climate change. Can J Bot 81:1145-1152

> Brown JF (1997) Effects of experimental burial on survival, growth, and resource allocation of three species of dune plants. J Ecol 85:151-158

Center TD (1994) Biological control of weeds: water hyacinth and water lettuce. Intercept, Andover

> D'Hertefeldt B, van der Putten WH (1998) Physiological integration of the clonal plant Carex arenaria and its response to soil-borne pathogens. Oikos 81:229-237

Danckwerts JE, Gordon AJ (1989) Long-term partitioning, storage and remobilization of ${ }^{14} \mathrm{C}$ assimilated by Trifolium repens (cv. Blanca). Ann Bot 64:533-544

Ding YH (1997) Studies on climate change and climate impact in China. China Meteorological Press, Beijing (in Chinese)

Ding J, Wang R, Fan Z, Chen Z, Fu W (1995) The distribution and importance of water hyacinth in China. Chinese $\mathrm{J}$ Weeds 9:49-51 (in Chinese with English abstract)

> Dong BC, Yu GL, Guo W, Zhang MX, Dong M, Yu FH (2010) How internode length, position and presence of leaves affect survival and growth of Alternanthera philoxeroides after fragmentation? Evol Ecol 24:1447-1461

Fry JD (1993) Freezing tolerance and carbohydrate content of low-temperature- acclimated and nonacclimated centipede grass. Crop Sci 33:1051-1055

Hellmann JJ, Byers JE, Bierwagen BG, Dukes JS (2008) Five potential consequences of climate change for invasive species. Conserv Biol 22:534-543

IPCC (2007) Climate change 2007: impacts, adaptation and vulnerability. Intergovernmental Panel on Climate Change, Cambridge University Press, New York, NY

Julien MH, Bourne AS (1988) Alligator weed is spreading in Australia. Plant Prot Q 3:91-96

- Karl TR, Jones PD, Knight RW, Kukla G and others (1993) Asymmetric trends of daily maximum and minimum temperature. Bull Am Meteorol Soc 74:1007-1023

Larcher W (1980) Physiological plant ecology. SpringerVerlag, New York, NY

> Li XB, Wu ZB, He GY (1995) Effects of low temperature and physiological age on superoxide dismutase in water hyacinth (Eichhornia crassipes Solms). Aquat Bot 50: 193-200

> Little LR, Maun MA (1996) The 'Ammophila problem' revisited: a role for mycorrhizal fungi. J Ecol 84:1-7

$>$ Liu CH, Yu D (2009) The bud and root sprouting capacity of Alternanthera philoxeroides after over-wintering on sediments of a drained canal. Hydrobiologia 623:251-256

> Lowe BJ, Watts RJ, Roberts J, Robertson A (2010) The effect of experimental inundation and sediment deposition on the survival and growth of two herbaceous riverbank plant species. Plant Ecol 209:57-69

Luu KT, Getsinger KD (1990) Seasonal biomass and carbohydrate percentage distribution in water hyacinth: smallscale evaluation. Technical Report A-90-1. US Army Corps of Engineers, Waterways Experiment Station, Vicksburg, MS

> Madsen JD (1991) Resource allocation at the individual 
plant level. Aquat Bot 41:67-86

Madsen JD, Luu KT, Getsinger KD (1993) Allocation of biomass and carbohydrates in water hyacinth (Eichhornia crassipes): pond-scale verification. Technical Report A93-3. US Army Corps of Engineers, Waterways Experiment Station, Vicksburg, MS

Maun MA (1998) Adaptations of plants to burial in coastal sand dunes. Can J Bot 76:713-738

Morgan JM (1984) Osmoregulation and water stress in higher plants. Annu Rev Plant Physiol 35:299-319

Owens CS, Madsen JD (1995) Low temperature limits of water hyacinth. J Aquat Plant Manage 33:63-68

$>$ Pan Y, Xie YH, Chen XS, Li F (2012) Effects of flooding and sedimentation on the growth and physiology of two emergent macrophytes from Dongting Lake wetlands. Aquat Bot 100:35-40

Rahel FJ, Olden JD (2008) Assessing the effects of climate change on aquatic invasive species. Conserv Biol 22: 521-533

Stuefer JF, Huber H (1999) The role of stolon internodes for ramet survival after clone fragmentation in Potentilla anserina. Ecol Lett 2:135-139

Sytsma MD, Anderson LWJ (1993) Biomass, nitrogen, and phosphorus allocation in parrotfeather (Myriophyllum aquaticum). J Aquat Plant Manag 31:244-248

Editorial responsibility: Christine Paetzold, Oldendorf/Luhe, Germany
Tyndall RW (1982) Nuisance aquatic plants and aquatic plant management programs in the United States, Vol 1, Southwestern Region. The Mitre Corporation, McLean, VA

> van der Putten WH, van Dijk C, Peters BAM (1993) Plantspecific soil-borne diseases contribute to succession in foredune vegetation. Nature 362:53-56

Villamagna AM, Murphy BR (2010) Ecological and socioeconomic impacts of invasive water hyacinth (Eichhornia crassipes): a review. Freshw Biol 55:282-298

> Volenec JJ, Ourry A, Joern BC (1996) A role for nitrogen reserves in forage regrowth and stress tolerance. Physiol Plant 97:185-193

Wilson JR, Holst N, Rees M (2005) Determinants and patterns of population growth in water hyacinth. Aquat Bot 81:51-67

Xie YH, Wen MZ, Yu D, Li YK (2004) Growth and resource allocation of water hyacinth as affected by gradually increasing nutrient concentrations. Aquat Bot 79:257-266

> Yu FH, Chen YF, Dong M (2002) Clonal integration enhances survival and performance of Potentilla anserina, suffering from partial sand burial on Ordos plateau, China. Evol Ecol 15:303-318

Zhang J, Maun MA (1990) Effects of sand burial on seed germination, seedling emergence, survival, and growth of Agropyron psammophilum. Can J Bot 68:304-310

Submitted: December 3, 2012; Accepted: June 21, 2013

Proofs received from author(s): August 13, 2013 